\title{
THE HISTORY OF THE EUROPEAN ASSOCIATION OF MUSEUMS OF HISTORY OF MEDICAL SCIENCES (EAMHMS)
}

\author{
INGER WIKSTRÖM-HAUGEN \\ Director Emerita of the Medical History Museum of Gothenburg, Sweden
}

\section{THREE JUBILEES IN 2013}

This year, 2013, we can celebrate three jubilees. It is 30 years since the Association was founded; it is also 200 years since Claude Bernard was born and 20 years since the first workshop was held.

\section{THE FOUNDING OF THE EAMHMS}

The Association was founded in 1983 on the initiative of Mlle Jacqueline Sonolet. She was then the curator and director of the Medical History Museum of the University Descartes in Paris but also very much involved in the management of the medical-historical Claude Bernard Museum outside Lyon.

A couple of months earlier, she had written to other medical history museums in Europe and asked if there might be an interest of to have an association for specific medical museum matters and issues. Some of us as well as herself were already members of the old, distinguished French Societé International de l'Histoire de la Médecine (SIHM) where, however, most of the members were neither acquainted with nor even interested in practical museum work and such questions as collecting, preservation, restoration and arrangement of exhibitions.

Metaphorically speaking, there was also another person behind her, namely Dr. Charles Mérieux, a very rich French pharmaceutical vaccine manufacturer in Lyon, who was willing to support financially. His trust, the Fondation Marcel Mérieux, was the owner of the Claude Bernard Museum, which had been opened for the public in 1965. The museum had earlier been the home of Claude Bernard, the father of experimental physiology (see below). 
The origin of Mérieux's interest in the history of medicine is said to be that his father, the biochemist Marcel Mérieux (1870-1937), had worked as a delivery boy to the founder of bacteriology Louis Pasteur (1822-1895).

\section{CLAUDE BERNARD 1813-1878}

Prof. Dr. Claude Bernard was born 200 years ago in a small cottage in SaintJulien-en-Beaujolais about $30 \mathrm{~km}$ northwest of Lyon on 12 July 1813 as the son of a farm worker. In spite of his poor background, the clever boy became a famous and wealthy scientist and philosopher as time went on. When he finally retired, he bought the small cottage of his childhood and built a big mansion next to it. He also established a vineyard, which always had been one of his dreams. Thanks to Charles Mérieux, both the cottage and the mansion became museums but not the vineyard where a nice Beaujolais wine has been produced until our days.

After the foundation of the EAMHMS, the Claude Bernard Museum became the main seat of the Association and the meeting place of its Board every second year.

\section{EAMHMS}

The first meeting of the European Association of Museums of History of Medical Sciences took place at the Claude Bernard Museum from 17 to 19 September 1983. We were 34 participants from ten countries. I was one of them. In the following year, I became a member of the Board and later the first Vice President and Senior Adviser. Therefore, I have a lot of memories from the long life of EAMHMS, which until now has arranged 16 international biannual Congresses, most of them with printed Actas, and 10 biannual Workshops in different European countries and cities.

The Congresses have been held in Lyon (1983), London (1984), Ingolstadt (1986), Pavia (1988), Barcelona (1990), Leiden (1992), Zürich (1994), Gothenburg (1996), Leeds (1998), Porto (2000), Paris (2002), Vienna (2004), Riga (2006), Edinburgh (2008), Copenhagen (2010) and Berlin (2012). I have been to all of them, except the two last ones. The next congress will be held in London again in 2014.

During the years, the Association has had four presidents. The first one was Dr. Brian Bricegirdle of the Science (and Wellcome) Museum in London. His 
successor was Prof. Dr. Christa Habrich of Deutsches Medizinhistorisches Museum in Ingolstadt and after her Madame Marie-Véronique Clin of the Descartes Museum in Paris (2004). Last year (2012), Prof. Dr. Thomas Schnalke of the Charitée Museum in Berlin became president.

\section{HISTORY OF THE EAMHMS WORKSHOPS}

This year, 2013, also means that twenty years have passed since the first Workshop was held in Riga, Latvia, in 1993 on the initiative of Prof. Dr. Karl Aarons, Director of the Paul Stradin Museum of the History of Medicine. After that Workshops have been held in Kaunas, Minsk (1995), once again Riga (1997), Saint Petersburg (1999), Wroclaw (2001), once again Kaunas (2005), Zagreb (2007), Cluj-Napoca (2009) and Kiev (2011). I have only had the opportunity to take part in the two last mentioned.

Mr. Willem J. Mulder, Board Member of the EAMHMS, Curator Emeritus of the Utrecht University Museum and primus motor in arranging of the Workshops and Mrs. Angele Rudzianskaite, Curator of the Lithuanian Museum of Pharmacy and Medical History in Kaunas, have written a detailed article about the history of the Workshops in the EAMHMS Bulletin, No. 49, July 2011.

\section{TODAY}

Jacqueline Sonolet died suddenly already in 1993 at the age of 77 and Charles Mérieux in 2001 at the age of 94, but the European Association of the History of Medical Sciences is still alive. The Claude Bernard Museum has, however, been taken over by a local historical society and the Board meetings have been held at the Descartes Museum in Paris for a couple of years.

As Congresses, Workshops and Board meetings do not get financial contributions any longer from the Fondation Mérieux, there a search is always going on for people willing to support with money. But maybe we do not need as much money nowadays as before, as the new digital world has given us a lot of aids we did not have earlier. Actas, the Bulletin, photos, pictures and texts can now be digitally printed and distributed very easily almost without costs. We can communicate and meet on the net where we can also get everything immediately translated from one language to another. Although this is marvellous, it must not totally replace personal meetings. I hope you agree with me. 


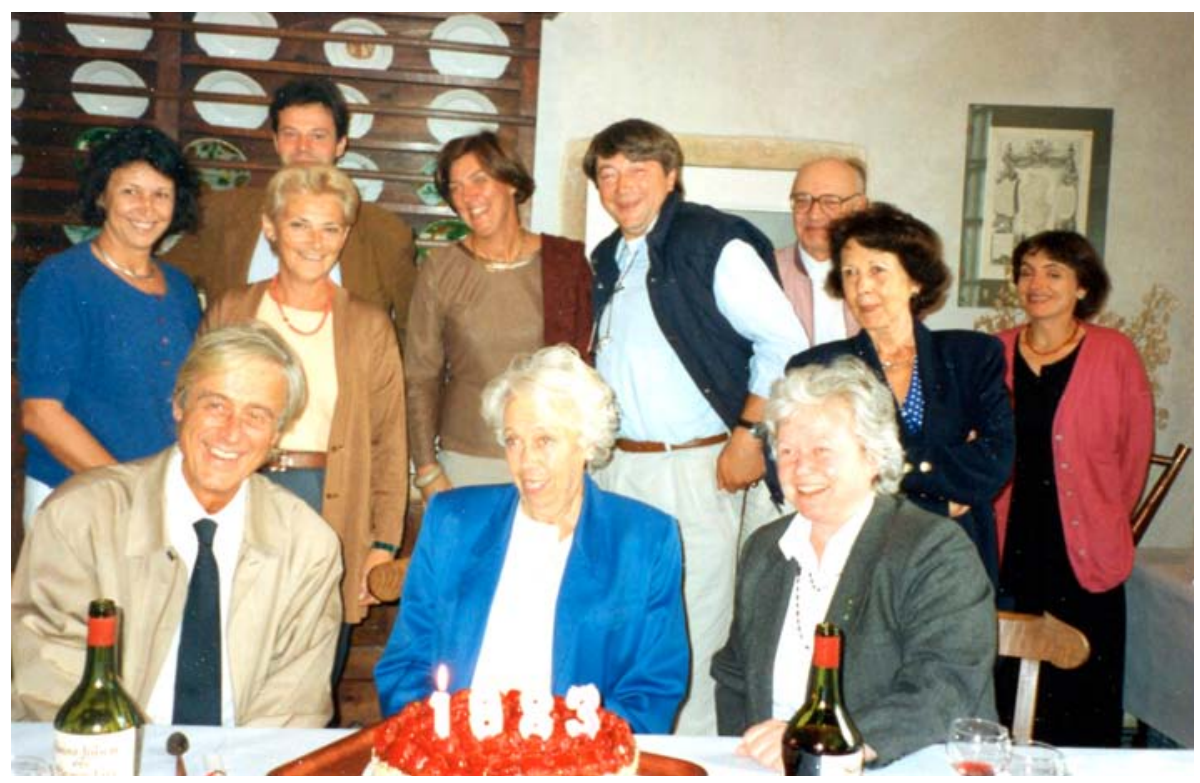

Mlle Jacqueline Sonolet and the Board celebrate the 10th birthday of the EAMHMS at the Claude Bernard Museum in 1993. Photo: Inger Wikström-Haugen.

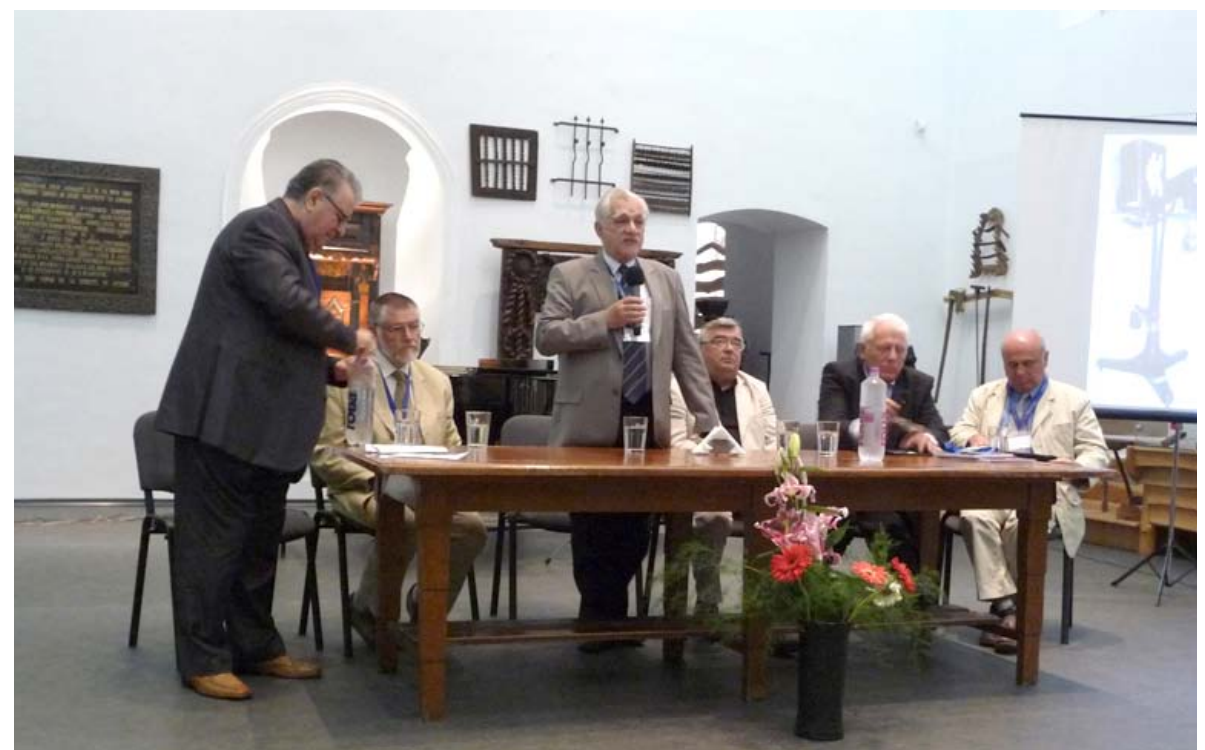

From the Workshop in Cluj-Napoca in 2009. Our host and colleague Prof.Dr. Pompiliu Manea and Willem J. Mulder with representatives of the University, the Region and the City. Photo: Bertil Haugen. 




Participants of the Workshop In Kiev in 2011 at the impressive Medical History Museum there. Photo: Bertil Haugen.

\section{Address for correspondence:}

Dr. Inger Wikström-Haugen

Jenny Lindsgatan 18, SE-416 62 Gothenburg, Sweden

E-mail: inger.whaugen@comhem.se 